\title{
Suorakylvön vaikutus kevätviljojen viljelyn työnmenekkiin
}

\author{
Markku Lätti, Työtehoseura, maatalousosasto,PL 13,05201Rajamäki,markku.latti@tts.fi
}

\begin{abstract}
Johdanto
Viljan hinta on viimeisen kymmenen vuoden aikana romahtanut noin neljäsosaan 1990-luvun alun hintatasosta. Euroopan Unioniin liittymisen jälkeen viljan hinta on kuitenkin lähes sama kaikkialla EU:n sisällä. Samaan aikaan Suomalaiselle maataloudelle on tyypillistä alhaiset hehtaarisadot ja suuret tuotantokustannukset verrattuna Euroopan tärkeimpiin maatalousmaihin. Jotta viljanviljelymme säilyisi kilpailukykyisenä, on viljelyn tulosta saatava parannettua. Kilpailukyvyn säilyttämiseksi on pyrittävä tehostamaan tuotantoa pienentämällä tuotantokustannuksia, jotka johtuvat Suomessa pääosin pienestä tilakoosta ja suurista koneiden yksikkökustannuksista, sekä lyhentämällä työaikaa. Gallup Elintarviketiedon tekemässä kyselyssä nurmiviljelystä on vapautumassa vuoteen 2007 mennessä 30 000-40 000 ha peltoa, joka siirtyy pääosin viljantuotantoon. Kun tilojen peltoala kasvaa, merkitsee se tiloilla investointien ja työmäärän lisääntymistä.
\end{abstract}

Tilojen koon kasvaessa on entistä tärkeämpää kiinnittää huomiota työn tehostamiseen. Tiloilla on käytettävissä rajallinen määrä resursseja, joilla työt on saatava tehdyksi. Tilakoon kasvaessa ne eivät välttämättä enää riitä töiden oikea-aikaiseen suorittamiseen. Viljelijällä on tilanteesta selvitäkseen vaihtoehtoina ulkoistaa töitä urakoitsijoille, tehdä yhteistyötä muiden viljelijöiden kanssa tai tehostaa tilan työketjuja. Viljanviljelyn työnmenekkiä on lähdetty pienentämään muun muassa siirtymällä suorakylvöön, jossa vilja kylvetään suoraan kasvipeitteiseen maahan ilman erillisiä muokkaustoimenpiteitä.

Suorakylvöön siirtymisen odotetaan pienentävän huomattavasti kevätviljojen viljelyn työnmenekkiä peltohehtaaria kohti työvaiheiden vähentyessä. Suorakylvön oletetaan myös selkeyttävän töiden suunnittelua. Yhteen sovitettavia työvaiheita on vähemmän kuin perinteisissä menetelmissä. Koneiden vaihtoa on vähemmän ja siirtoajoon kuluu vähemmän aikaa kuin ennen. Suorakylvömenetelmä onkin yleistynyt Suomessa viime vuosina voimakkaasti, mutta tutkittua työnmenekkitietoutta Suomen olosuhteissa ei ole juuri aikaisemmin ollut olemassa. Suomalaisilla tiloilla on perinteisesti ollut kaikki koneet omasta takaa ja ne ovat monesti vajaakäytössä. Viljanviljelykalustoinvestointia miettivän viljelijän onkin vaikeaa tehdä perusteltuja päätöksiä koneellistamisasteesta, jos ei tiedetä, kuinka paljon aikaa kevättöihin kuluu milläkin koneketjulla ja menetelmällä.

Tutkimuksen tarkoituksena oli selvittää, kuinka paljon suorakylvöllä on mahdollista pienentää viljanviljelyn työnmenekkiä Suomalaisissa olosuhteissa. Tutkimus tehtiin Työtehoseurassa ja se liittyy osana MTT:ssa käynnissä olevaan Kevätviljojen suorakylvö -hankkeeseen.

\section{Aineisto ja menetelmät}

Kevätviljojen suorakylvön työnmenekkiä selvitettiin vuosina 2002 ja 2003 käytännön viljelijöiden pelloilla tehdyin työntutkimuksin. Työntutkimuksia tehtiin yhteensä yhdeksällä tilalla Etelä-Suomen alueella. Tilat valittiin pääasiassa suorakylvökonemerkin perusteella. Tutkimukseen haluttiin saada mahdollisimman monipuolinen valikoima eri tyyppisiä suorakylvökoneita, jotta mahdolliset koneista johtuvat erot työnmenekeissä eivät vaikuttaisi lopputulokseen. Työntutkimuksissa mukana olleet konemerkit ja mallit olivat VM (Vieskan Metalli) 3000 SK, Kongskilde Demeter Multiseed 3000, Tume Agrimaster 3000, Simulta Super Seed 3000, Krause 5313 (4m), VM 4000.

Yhteensä tutkimuksessa kylvetty peltopinta-ala oli noin 40 hehtaaria. Maalajit vaihtelivat karkeasta hiedasta aitosaveen ja runsasmultaiseen multamaahan saakka. Kaikki suorakylvöt tehtiin edellisvuotiseen viljansänkeen keväällä. Tutkimustiloiksi valittiin suorakylväjiä, joilla oli vähintään yhden vuoden kokemus suorakylvöstä ja suorakylvökoneesta. Työ- ja kylvömenetelmät olivat tiloilla näin ollen rutinoituneet riittävästi ja työntutkimusta voitiin pitää luotettavana. Tilalla tutkimuskohteeksi valittiin tyypiltään keskimääräinen lohko, joka vastasi alueen kylvöolosuhteita tutkimusaikana. Tiloilla tutkittiin vähintään yhden lohkon koko kylvötyönmenekki, jonka pinta-ala oli yli 2 ha. Useilla tiloilla kylvötyötä seurattiin kahdella tai kolmella eri lohkolla. Kylvötyön ohella tutkittiin lohkokohtaisia aloittelu- ja lopettelutöitä sekä kylvökoneen siemen ja lannoitesäiliöiden täyttötyötä. Lisäksi kiinnitettiin huomiota huoltoaikoihin, siirtymisiin kuluvaan aikaan sekä mahdollisiin häiriötilanteisiin.

Koko tutkittavan lohkon vaatima työaika mitattiin. Kylvötyöstä eroteltiin varsinainen kylvöaika, kääntymisiin eri menetelmillä kulunut aika, tyhjäajo sekä mahdolliset häiriöajat. Täyttötyöstä mitattiin siirtymisaika pellolta täyttöpaikalle ja takaisin pellolle, täytön valmistelu- ja lopetteluaika, varsinainen 
täyttötyöaika eri menetelmillä sekä mahdolliset häiriötilanteet. Tyypillisimpiä kylvötyön häiriöitä olivat esteiden (pylväät, kivet, kiviriutat) kiertäminen ja maan aiheuttamat häiriöt. Tutkimusvuonna 2003 kevään sää oli melko sateinen, joten kylvöjä jouduttiin tekemään melko märkään maahan. Kaikilla tutkitulla tiloilla kylvö kuitenkin onnistui normaalisti. Tyypillisiä maan aiheuttamia häiriöitä olivat vantaiden tukkeutuminen edellisvuotisesta runsaasta olkimassasta ja/tai kosteasta maasta johtuen.

Mittauksiin käytettiin tiedonkeruulaitetta (RUFCO-field computer), josta tiedot siirrettiin tietokoneelle jatkokäsittelyä varten. Varsinaisen aikamittauksen lisäksi mitattiin myös kylvötyön ajonopeus, käsiteltyjen materiaalien määrä, lohkojen pinta-ala, ajokaistan pituus ja päisteiden leveys. Kylvön ajonopeus selvitettiin useina kerranteina mittaamalla ajokaistalla kylvöön käytetty matka ja aika. Pinta-alan ja matkan mittaukseen käytettiin GPS-laitetta. Kenttätyövaiheen jälkeen työntutkimustiedoista laskettiin keskimääräinen ajonopeus ja kääntymisaika eri työleveyksisille suorakylvökoneille. Samoin laskettiin työaika eri täyttömenetelmillä. Mittauksista saatujen työaikatietojen perusteella laskettiin työnmenekki 2 hehtaarin kokoiselle standardiperuslohkolle, joka on suorakaiteen muotoinen 100 metriä x 200 metriä. Pääajosuunta on suoran sivun suuntainen.

Mitattujen arvojen perusteella laskettiin suoritusajan työnmenekki, joka sisältää perustyöajan lisäksi varauksen häiriöille ja elpymislisän. Suoritusajan työnmenekki kuvaa parhaiten pellolla tapahtuvaa käytännön työtä. Häiriö- ja elpymislisä ilmoitetaan \%-lisänä varsinaiseen suoritusaikaan. Elpymislisä määräytyy lähinnä työn raskauden perusteella. Elpymislisä on mitoitettu niin, että normaalikuntoinen, ammattitaitoinen henkilö pystyy elpymistaukoja pitäen tekemään ko. työtä koko työpäivän rasitustason pysyessä kohtuullisena. Kylvötyön elpymisprosenttina laskelmissa käytettiin $8 \%$ :ia ja kylvökoneen täytön elpymisprosenttina 2,5 \%:ia. Häiriöaika käsittää työssä normaalisti esiintyvät häiriöt ja niiden poistamiseen kuluvan ajan. Kylvötyön sekä kylvökoneen täytön häiriöprosenttina laskelmissa käytettiin $6 \%$ :ia.

Aineiston perusteella laskettuja tuloksia vertailtiin eri muokkaus- ja kylvömenetelmien työnmenekkeihin, jotka laskettiin Työtehoseuran aikaisempiin työntutkimuksiin pohjautuen. Työnmenekit laskettiin viidelle eri kylvöpinta-alalle $(50,100,150,200$ ja 400 ha) ja laskennan pohjana käytettiin pintaaloja vastaavia työkoneketjuja. Saatuja tuloksia suorakylvön työnmenekistä verrattiin myös aikaisemmin Pohjoismaissa suorakylvöstä saatuihin tuloksiin ja suorakylväjille Työtehoseurassa vuonna 2002 tehdystä kyselytutkimuksesta saatuihin tuloksiin.

\section{Tulokset ja niiden tarkastelu}

Taulukoiden lukuja tarkastellessa täytyy muistaa, että ne ovat sovellettavissa vain kyseisille työketjuille. Käytössä olevia työketjuja on huomattavasti enemmän, mutta niiden esittäminen tässä yhteydessä on mahdotonta. Tuloksista näkee kuitenkin sen suuruusluokan, missä kyseisillä menetelmillä liikutaan.

Taulukko 1. Työnmenekkivertailussa käytetyt työketjut ja niiden työnmenekit h/ha sekä kapasiteetti ha/h. Taulukossa on esitetty myös suhdeluku, joka kuvaa prosentuaalisesti sitä aikaa, joka kullakin työketjulla menee verrattuna taulukossa ensimmäisenä esitettyyn työketjuun verrattuna. Taulukossa esitetyt luvut on laskettu 100 hehtaarin ja 200 hehtaarin kylvöpinta-aloja vastaavilla koneketjuilla.

\begin{tabular}{|l|c|c|c|c|c|c|}
\hline \multicolumn{1}{l|}{} & $\mathrm{A}$ & $\mathrm{B}$ & $\mathrm{C}$ & $\mathrm{D}$ & $\mathrm{E}$ & $\mathrm{F}$ \\
\hline Kyntö & $\mathrm{X}$ & $\mathrm{X}$ & & & & \\
\hline Sänkimuokkaus & & & $\mathrm{X}$ & $\mathrm{X}$ & $\mathrm{X}$ & \\
\hline Sänkimuokkaus & & & $\mathrm{X}$ & & $\mathrm{X}$ & \\
\hline Tasausäestys & $\mathrm{X}$ & & $\mathrm{X}$ & $\mathrm{X}$ & & \\
\hline Kylvömuokkaus & $\mathrm{X}$ & $\mathrm{X}$ & & $\mathrm{X}$ & & \\
\hline Kylvömuokkaus & $\mathrm{X}$ & $\mathrm{X}$ & & $\mathrm{X}$ & & $\mathrm{X}$ \\
\hline Juolavehnän torjunta & & & & & & \\
\hline Normaali kylvö & $\mathrm{X}$ & $\mathrm{X}$ & & $\mathrm{X}$ & $\mathrm{X}$ & \\
\hline Jyrsintä + kylvö & & & $\mathrm{X}$ & & & $\mathrm{X}$ \\
\hline Suorakylvö & & & & & & \\
\hline Jyräys & $\mathrm{X}$ & & & $\mathrm{X}$ & $\mathrm{X}$ & $\mathrm{X}$ \\
\hline Kasvinsuojeluruiskutus & $\mathrm{X}$ & $\mathrm{X}$ & $\mathrm{X}$ & $\mathrm{X}$ & $\mathrm{X}$ & $\mathrm{X}$ \\
\hline Kasvinsuojeluruiskutus & $\mathrm{X}$ & $\mathrm{X}$ & $\mathrm{X}$ & & & \\
\hline YHTEENSÄ h/ha & $3,66-3,09$ & $2,92-2,53$ & $2,72-2,10$ & $2,46-1,94$ & $1,98-1,55$ & $1,23-0,97$ \\
\hline Suhdeluku & 100 & $80-82$ & $74-68$ & $67-63$ & $54-50$ & $34-32$ \\
\hline Kapasiteetti ha/h & $0,27-0,32$ & $0,34-0,40$ & $0,37-0,48$ & $0,41-0,52$ & $0,50-0,64$ & $0,81-1,03$ \\
\hline
\end{tabular}


Taulukko 2. Työnmenekkivertailussa käytetyt työketjut ja niiden työnmenekit h/ha sekä kapasiteetti ha/h. Taulukossa on esitetty myös suhdeluku, joka kuvaa prosentuaalisesti sitä aikaa, joka kullakin työketjulla menee verrattuna taulukossa ensimmäisenä esitettyyn työketjuun verrattuna. Taulukossa esitetyt luvut on laskettu 50 hehtaarin ja 400 hehtaarin kylvöpinta-aloja vastaavilla koneketjuilla.

\begin{tabular}{|c|c|c|c|c|c|c|}
\hline & $\mathrm{A}$ & $\mathrm{B}$ & $\mathrm{C}$ & $\mathrm{D}$ & $\mathrm{E}$ & $\mathrm{F}$ \\
\hline Kyntö & $\mathrm{X}$ & $\mathrm{X}$ & & & & \\
\hline Sänkimuokkaus & & & $\mathrm{X}$ & $\mathrm{X}$ & $\mathrm{X}$ & \\
\hline Sänkimuokkaus & & & $\mathrm{X}$ & & $\mathrm{X}$ & \\
\hline Tasausäestys & $\mathrm{X}$ & & $\mathrm{X}$ & $\mathrm{X}$ & & \\
\hline Kylvömuokkaus & $\mathrm{X}$ & $\mathrm{X}$ & & $\mathrm{X}$ & & \\
\hline Kylvömuokkaus & $\mathrm{X}$ & $\mathrm{X}$ & & $\mathrm{X}$ & & \\
\hline Juolavehnän torjunta & & & & & & $\mathrm{X}$ \\
\hline Normaali kylvö & $\mathrm{X}$ & $\mathrm{X}$ & & $\mathrm{X}$ & $\mathrm{X}$ & \\
\hline Jyrsintä + kylvö & & & $\mathrm{X}$ & & & \\
\hline Suorakylvö & & & & & & $\mathrm{X}$ \\
\hline Jyräys & $\mathrm{X}$ & & & & & \\
\hline Kasvinsuojeluruiskutus & $\mathrm{X}$ & $\mathrm{X}$ & $\mathrm{X}$ & $\mathrm{X}$ & $\mathrm{X}$ & $\mathrm{X}$ \\
\hline Kasvinsuojeluruiskutus & $\mathrm{X}$ & $\mathrm{X}$ & $\mathrm{X}$ & $\mathrm{X}$ & $\mathrm{X}$ & $\mathrm{X}$ \\
\hline YHTEENSÄ h/ha & $4,56-2,78$ & $3,67-2,22$ & $3,06-2,05$ & $2,82-1,84$ & $2,25-1,51$ & $1,36-0,91$ \\
\hline Suhdeluku & 100 & 80 & $67-74$ & $62-66$ & $49-54$ & $30-33$ \\
\hline Kapasiteetti ha/h & $0,36-0,22$ & $0,27-0,45$ & $0,49-0,33$ & $0,54-0,36$ & $0,66-0,45$ & $1,25-0,86$ \\
\hline
\end{tabular}

Tutkimuksen mukaan suorakylvön (työketju F) työnmenekki vaihtelee kylvettävästä peltopinta-alasta ja käytettävästä konekannasta riippuen 0,91 tunnista hehtaarilla (h/ha) 1,36 tuntiin per hehtaari $(\mathrm{h} / \mathrm{ha})$ (taulukko 2). Toisessa ääripäässä kyntöön perustuvan kylvön (työketju A) työnmenekki vaihtelee 2,78 tunnista hehtaarilla (h/ha) 4,56 tuntiin per hehtaari (h/ha) (taulukko 2). Suorakylvön käyttöönotolla voidaan työaikaa ääritapauksissa säästää yli kolme tuntia hehtaarilla. Prosentuaalisesti suorakylvön työnmenekki on 30-34 \% kyntöön perustuvan kylvön työnmenekistä. Kevennettyyn muokkaukseen perustuvien kylvömenetelmien (työketjut D ja E) työnmenekki on tämän tutkimuksen perusteella 18 - 33 \% suurempi kuin suorakylvön. Suorakylvön kapasiteetti on $0,81-1,25$ ha/h, kun kyntöön perustuvalla kylvöllä se on $0,22-0,36$ ha/h ja kevennettyyn muokkaukseen perustuvilla kylvöillä $0,36-0,66 \mathrm{ha} / \mathrm{h}$. Jyrsinkylvön (työketju C) kapasiteetti on $0,33-0,49 \mathrm{ha} / \mathrm{h}$.

Tutkimuksessa saadut tulokset ovat yhteneväisiä muista Pohjoismaista aikaisemmin saatujen tulosten kanssa. Vaikka koneketjut perinteisissä kylvöissä eivät olekaan aivan samat, on työnmenekin säästö suorakylvöön siirryttäessä samaa suuruusluokkaa. Tanskassa tehdyissä tutkimuksissa suorakylvö sänkeen vähensi työmäärää $70 \%$ kevätviljojen viljelyssä ja $75 \%$ syysviljojen viljelyssä tavanomaiseen kylvömenetelmään verrattuna (Nielsen 1987). Ruotsissa vastaava säästö kevätviljojen viljelyssä oli 75 \% (Danfors 1988). Työtehoseuran vuonna 2002 tekemässä kyselyssä suorakylväjille viljelijät ilmoittivat työnmenekin vähentyneen keskimäärin kolmasosaan suorakylvöön siirtymisen myötä (Lätti 2002). Kuvassa 1. on esitetty eri työketjujen työnmenekit kaikkia tutkittuja kylvöpinta-aloja vastaavilla koneketjuilla.

Kuva 1. Eri kylvömenetelmien työnmenekit 50, 100, 150, 200 ja 400 hehtaarin kylvöpinta-aloja vastaavilla koneketjuilla.
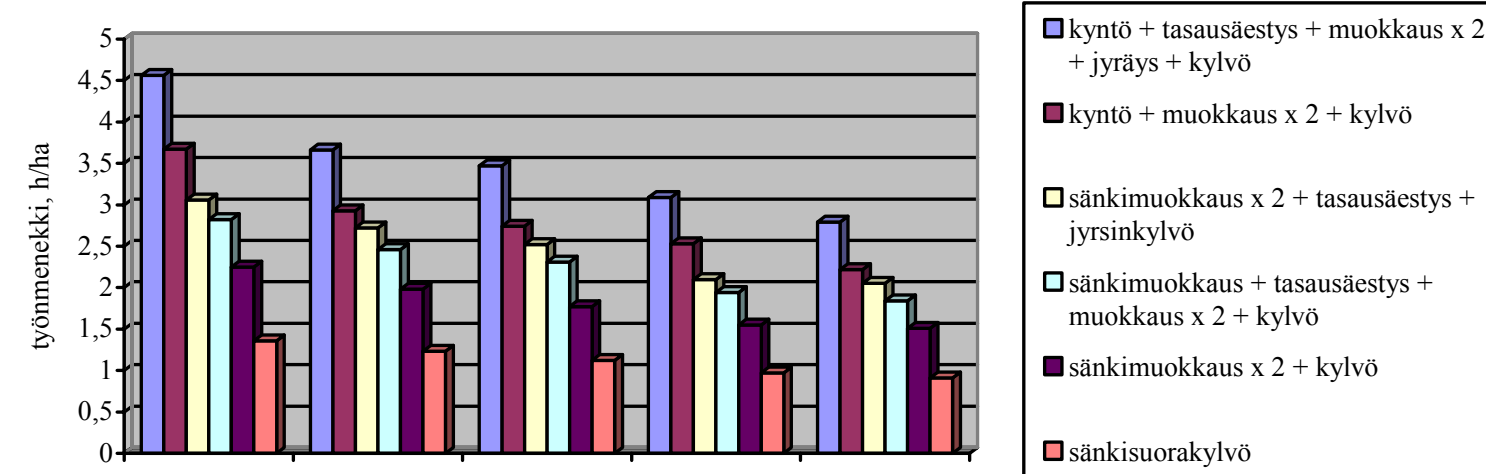


\section{Johtopäätökset}

Suorakylvöllä saavutettava työaikasäästö on tervetullut etenkin suuremmille viljanviljelytiloille ja tiloille, jotka kasvattavat viljelypinta-alaansa voimakkaasti. Ammattitaitoista työvoimaa ei ole saatavissa takavuosien malliin, kun väki maaseudulta vähenee ja tekniikka maataloudessa lisääntyy. Vaarana on, että kylvötöitä ei enää saada suoritettua niiden optimaaliseen aikaan, jolloin satotaso kärsii. Etenkin samaan aikaan kuivuvilla savimailla on tärkeää, että kylvötyöt saadaan tehtyä optimaaliseen aikaan. Äärimmäisessä tapauksessa sitä on vain noin viikko. Käytettäessä suorakylvöä optimaalinen kylvöaika saadaan hyödynnettyä parhaiten. Nykytietämyksen mukaan suorakylvön optimaalinen kylvöaika on noin viikon perinteistä kylvöaikaa myöhäisempi.

Tässä tutkimuksessa laskettujen kylvöketjujen ulkopuolelle jää suuri joukko eri vaihtoehtoja, joita viljelijöillä on käytössä, joten lasketut työnmenekit ovat vain suuntaa-antavia. Käytettävän koneketjun lisäksi työnmenekkiin vaikuttaa myös muut tilan olosuhteet, kuten peltolohkojen koko ja muoto sekä niiden etäisyys talouskeskuksesta. Pienillä ja epäsäännöllisillä tai avo-ojitetuilla lohkoilla eri työvaiheiden työnmenekit ovat suurempia kuin työntutkimuksilla saadut arvot, joten silloin niitä täytyy korjata kertoimen avulla. Viljelijän onkin menetelmämuutosta harkitessaan laskettava suorakylvöön siirtymisellä saavutettava työajan säästö käyttäen lähtötietoina oman tilansa tietoja.

Monesti suorakylvöä tekevillä tiloilla joudutaan käyttämään muitakin viljelymenetelmiä suorakylvön rinnalla. Tähän voivat olla syynä muun muassa olosuhteet, jotka eivät salli suorakylvömenetelmän käyttöä jonakin vuonna tai jollakin lohkolla. Muokkausta voidaan joutua käyttämään esimerkiksi lannan tai kalkin multaamiseen tai kosteusolojen ja pellon pinnan epätasaisuuksien tasaamiseen. Kyntäminen voi olla perusteltua muutaman vuoden välein tiivistyneen pintamaan kuohkeuttamiseksi. Lisäksi, jos tilalla viljellään sokerijuurikasta tai perunaa, on nämä pellot joka tapauksessa muokattava. Muokkaus voi olla perusteltua myös ympäristösyistä, jos pintamaahan kertyy liiaksi fosforia, joka huuhtoutuu pintavirtausten mukana. Muun muassa näistä syistä johtuen on erityisen tärkeää tehdä vertailuja tilakohtaisesti erilaisten koneketjuvaihtoehtojen soveltuvuudesta juuri omaa tilaa ajatellen ottaen huomioon oman tilan erityispiirteet, koneiden yhteiskäyttömahdollisuus, urakointimahdollisuus jne.

Samoin on tehtävä vertailulaskelmia investoinnin kannattavuudesta tilakohtaisten tietojen pohjalta. Vaikka työmäärä suorakylvössä vähenee tapauskohtaisesti huomattavastikin, ei se vielä välttämättä riitä tekemään investoinnista kannattavaa etenkään pienemmillä kylvöpinta-aloilla. Pienempien tilojen kannattaakin harkita suorakylvökoneen yhteishankintaa, jolloin sillä vuosittain kylvettävä peltopinta-ala on suurempi ja kustannukset jakautuvat useamman tilan kesken. Yhteishankinnalla on mahdollisesti myös hankkia isompi kylvökone, jonka työmenekki on suurempi. Yksin sellaiseen investointiin ei välttämättä ole resursseja. Myös urakointia tai sen hyväksikäyttöä kannattaa miettiä. Urakointi on lisääntynyt viime vuosina voimakkaasti ja yleensä urakoijalla on hyvä kalusto ja hänen ammattitaitonsa on keskivertoa parempi.

\section{Kirjallisuus:}

Danfors, B. 1988. Bränsleförbrukning och avverkning vid olika system för jordbearbetning och sådd: olika sätt att spara motorbränsle och öka kapaciteten. Jordbrukstekniska institutet. Meddelande 420.

Lätti, M. 2002. Suorakylvöä käytännössä - käyttäjien kokemuksia. Työtehoseuran maataloustiedote 8/2002 (548). Nielsen, V. 1987. Energiforbrug og arbejdsbehov ved direkte såning og traditional jordbehandling. Statens jordbrukstekniske forsög. Beretning 37 . 